\title{
Impact of Organizational Culture to Information Security Triad
}

\author{
Puspita Kencana Sari \\ Faculty of Economic and Business, Telkom University, \\ Bandung, Indonesia
}

\author{
Rully Satriawan Deniharza \\ Faculty of Economic and Business, Telkom University, \\ Bandung, Indonesia
}

\begin{abstract}
In many organizations, the implementation of information security management have some barriers. Some of them are related with the employees, such as resistance and lack of awareness to make information security policies and procedures. Those things can be influenced by the organizational culture. Therefore, this paper explores the impact of organizational culture with three aspects of information security, i.e. confidentiality, integrity, and availability. In this paper, the characteristics of organizational culture consists of four constructions; cooperativeness, innovativeness, consistency, and effectiveness. This study used a quantitative method with multiple linier regression analysis. Data were taken by using questionnaire distributed to all employees of a telecommunication provider's customer service office. It shows that all dimensions of organizational culture significantly affect the implementation of information security triad simultaneously. Partially, organizational culture has a significant impact to confidentiality and integrity, but not to the availability.
\end{abstract}

Keywords: Organizational Culture, Confidentiality, Integrity, Availability, Information Security

\section{INTRODUCTION}

Information as one of important assets of an organization needs to be protected like any other assets. Information security is intended not only to protect organizationsôvaluable information, but also hardware and software to process the information [1]. Information security management (ISM) is more than computer security. ISM includes policies, process, procedures, organization structures, hardware and software functions that needs to be implemented [2]. Therefore, discussion about ISM does not merely examine technical things of security.

Many factors can affect the implementation of information security in an organization. A research on several organizations in Taiwan found the relation between organizational culture and information security management. It shows that organizations that have a flexibility culture would have more inhibitors in implementing their information security management [3]. Some organizational factors also have a significant impact to the effectiveness of implementing ISM, including IT competence of business managers, environment uncertainty, industry type, and organization size [4]. Another research also revealed that information security in some global financial services institutions also have significant correlations with some dimensions of national culture [5].

In this paper, we discuss about ISM relationship with the organizational culture, like Chang \& Lin did [3]. However, this paper took a different organization from a different country as the source of the case study, specifically in Indonesia. Organizational culture has some basic patterns that are accepted and adopted in an organization underlying the way of thinking, feeling, reacting, and acting of itôs members in resolving their problems [6] [7] [8]. Many researches have been done to study organizational culture. A study of some organizations in Singapore shows that cultural strength of organizations is related to the organizational performance measured by some financial indicators [9]. Organizational culture also has influenced some processes of information system (IS) development and implementation in an organization [10]. Information security management is related with the use of information in the organization along with the process of using the information system. Therefore, this study needs to explore more about the relationship between organizational culture and ISM.

Organizational culture can be described in some different dimensions among experts. Lee \& Yu defined organizational culture in their research in five dimensions, consisting of innovation, support, team, humanistic, and task [9]. Chang \& Lin concluded four characteristics of organizational culture that were divided in two dimensions; i.e. internal or external orientation and flexibility or control orientation, as described below [3].

a. Cooperativeness

This culture is built from internal-flexibility orientation that is characterized by cooperations among organization members, information sharing, trust, empowerment of employees and team work.

b. Innovativeness

This culture is built from external-flexibility orientation that is characterized by creativity, entrepreneurship, adaptability and dynamism.

c. Consistency

This culture is built from internal-control orientation that is characterized by order, rules and regulation, uniformity and efficiency.

d. Effectiveness 
This culture is built from external-control orientation that is characterized by competitiveness, goal achievement, production, effectiveness, and benefit-oriented measures.

Information security consists of three key aspects also called as information security triad, which consist of confidentiality, integrity, and availability [1]. Besides those aspects, information security can also include authenticity and non-repudiation [11]. Chang \& Lin also added accountability as information security aspect [3]. Confidentiality of information means the organization should protect its important and secret data and information to be accessed by unauthorized people. Availability has a goal to provide data and information for authorized people whenever it is needed. Integrity means the data and information provided by the organization should represent the real fact and condition.

From a research on Indonesian smartphone users in 2013, around $80 \%$ from the respondents had information security breach experiences, such as SMS Spam, Call Spam, data lost, malware, etc [12]. It shows that consumers of telecommunication providers also become a target of security threats. One way to access customersô data is through customersô service office. The office gives many services to their customer such as payment, complaint, or changes of their service types. They have many accesses to many data of the customers, such as personal data and billing. Therefore, the information security in that office should be well considered, not only to protect the companyôs data but also their consumersô If there is any security breach caused by a lack of security in that office, it can damage the reputation of the telecommunication provider. This research tries to find out the impact of an organizational culture to the implementation of information security management, taking a case study of a telecommunication provider customer service office in Indonesia.

\section{CONCEPTUAL FRAMEWORK}

The research framework adapted Chang \& Linô model [3] that investigated the relationship between organizational culture, represented by its four characteristics, and information security management, represented by four dimensions. However, this research only inspected the relationship within the three dimensions of information security known as information security triad. Not only studies the impact of organizational culture simultaneously to information security management but also reviews the relationship of organizational culture dimensions partially to each aspect of information security triad. It can be shown by Figure 1 below.

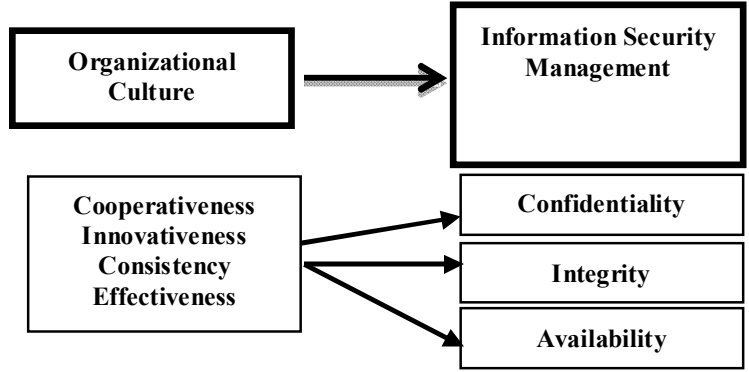

Fig. 1. Research Framework
From that framework, it can be defined four hypotheses as follows:

H1. Organizational culture significantly affects information security management

H2. Organizational culture significantly affects confidentiality aspect

H3. Organizational culture significantly affects integrity aspect

H4. Organizational culture significantly affects availability aspect

\section{Research Methods And Data}

This study used quantitative method to measure the effect of organizational culture to the information security triad, simultaneously and partially. It also used a descriptive approach to describe the organizational culture and information security management in a customer service office as a population observed. To prove the four hypotheses above, some variables that could be classified as the independent variable and the dependent variable were used. Independent variable is a variable that can affect and explain other variable (dependent variable) [13]. In this research, the independent variable was organizational culture that consists of Cooperativeness, Innovativeness, Consistency, and Effectiveness. Meanwhile, the dependent variable was the variable affected and could be explained by the independent variables [13]. Information security management with its information security triad (Confidentiality, Integrity, and Availability) became the dependent variables. Details of variables and sub variables of this research can be seen in Table 1.

Those indicators were used as basic for composing the questionnaire. For measurement, it used likert scale to define attitudes, opinions, and perceptions of a person or group of people about social phenomena [14]. Variety of answers in the questionnaire range from totally agree, agree, disagree, and totally disagree. All members of the office as the place for the case study became the sample of this research (census technique) because the total of the population was less than 30 persons.

TABLE I. OPERATIONAL VARIABLE

\begin{tabular}{|c|c|c|c|}
\hline Variable & Sub variable & Indicators & $\begin{array}{l}\text { Number } \\
\text { of Items }\end{array}$ \\
\hline \multirow[t]{4}{*}{$\begin{array}{c}\text { Organizational } \\
\text { Culture }\end{array}$} & Cooperativeness & $\begin{array}{l}\text { Cooperation, team } \\
\text { work, trust, } \\
\text { empowerment }\end{array}$ & 5 \\
\hline & Innovativeness & $\begin{array}{c}\text { Dynamism and } \\
\text { creativity }\end{array}$ & 5 \\
\hline & Consistency & $\begin{array}{l}\text { Order, rules and } \\
\text { regulation, efficiency }\end{array}$ & 6 \\
\hline & Effectiveness & $\begin{array}{c}\text { Goal achievement, } \\
\text { effectiveness }\end{array}$ & 4 \\
\hline $\begin{array}{l}\text { Information } \\
\text { Security }\end{array}$ & Confidentiality & $\begin{array}{c}\text { Access right, secrecy, } \\
\text { safety }\end{array}$ & 5 \\
\hline \multirow[t]{2}{*}{ Management } & Integrity & $\begin{array}{c}\text { Back-up, database } \\
\text { maintenance }\end{array}$ & 3 \\
\hline & Availability & $\begin{array}{c}\text { Availability, control, } \\
\text { resistance }\end{array}$ & 2 \\
\hline \multicolumn{3}{|c|}{ TOTAL ITEMS IN QUESTIONNAIRE } & 30 \\
\hline
\end{tabular}


Content validity describes the fitness of research instrument with what will be measured [13]. All items in the questionnaire had passed validity test using SPSS 21 with significant rate $10 \%(\mathrm{r}=0.317)$. The questionnaire also passed reliability test that showed its consistency in measuring the same symptoms [15]. For this research, it passed the test if Alpha Cronbach coefficient is more than 0.6. Using SPSS 21, this instrument had Alpha Cronbach coefficient 0.88. It means that this questionnaire is reliable to be used for data collection.

This research used two approaches in the data analysis, i.e. descriptive approach and statistical approach. Descriptive approach was used to describe respondent characteristics, organizational culture and information security management implementation in the customer service office. Meanwhile, statistical approach used multiple linier regression analysis to measure the impact of organizational culture to the information security management. It was used because the model in this research had more than one independent variable, which consists of Cooperativeness (X1), Innovativeness (X2), Consistency (X3), and Effectiveness (X4). It can be shown in a mathematical equation as below:

$\mathrm{Y}=\mathrm{a}+\mathrm{b} 1 \mathrm{X} 1+\mathrm{b} 2 \mathrm{X} 2+\mathrm{b} 3 \mathrm{X} 3+\mathrm{b} 4 \mathrm{X} 4+\mathrm{e}$

$\mathrm{Y}=$ Information security management is showed by Confidentiality, Integrity, Availability

$\mathrm{a}=$ constanta

b1 = Regression coefficient for cooperativeness

b2 = Regression coeffcient for innovativeness

b3 = Regression coefficient for concistency

$\mathrm{b} 4=$ Regression coefficeint for effectiveness

$\mathrm{X} 1=$ Cooperativeness variable

$\mathrm{X} 2=$ Innovativeness variable

$\mathrm{X} 3=$ Concistency variable

$\mathrm{X} 4=$ Effectiveness variable

$\mathrm{e} \quad=$ error disturbances

In this research, the constanta was not analysed because all variable used the same scale for measurement (ordinal scale).

\section{Results And Discussions}

The number of employees of the customer service office was 28 people. All of them became respondents for this research. Characteristics of the resepondents will be described by gender, education background, and age. By gender, $43 \%$ are men and $57 \%$ are women. By education background, $11 \%$ are graduates form senior high school, $36 \%$ from diploma, and the rest $54 \%$ from graduate and undergraduate school. By age, most of them (50\%) are 26-35 years old, 36\% are under 26 years old, and $14 \%$ are more than 35 years old.

Each item of the questionnaire was grouped by its subvariable. To describe the answer from each subvariable, some categories were defined based on the continuum line. The total of respondents are 28 persons with the highest scale of four and smallest scale of one. Then, it can be calculated that the highest cumulative score is 112 or $100 \%$ and the smallest is 28 or $25 \%$ with the interval values of $18.75 \%$ for four group . Therefore, we can get a category classification as shown in Table 2 below.

TABLE II. CATEGORY CLASSIFICATION

\begin{tabular}{|c|c|c|}
\hline No & Percentage & Category \\
\hline 1 & $25 \%-43.75 \%$ & Very Weak \\
\hline 2 & $>43.75 \%-62.5 \%$ & Weak \\
\hline 3 & $>62.5 \%-81.25 \%$ & Strong \\
\hline 4 & $>81.25 \%-100 \%$ & Very Strong \\
\hline
\end{tabular}

\section{A. Descriptive Analysis}

For the first step, all the answers from the questionnaire were recapitulated based on sub variables. Then, each sub variable was accumulated to get its total average and the percentage to define its category as it was defined in Table 2 above. Recapitulation of calculation for each sub variable can be seen in Table 3. From the results we concluded that among those four types of culture, none of them dominates the customer service office. All of them were in ñstrongò category. The biggest values refer to cooperativeness (80\%), meaning the office strongly implements cooperation, team work, trust, and empowerment manners in their daily operation. Meanwhile, the smallest value refers to the effectiveness $(78.8 \%)$ although itôs not too much different with other cultures.

TABLE III. DESCRIPTIVE FOR EACH SUB VARIABLE

\begin{tabular}{|c|c|c|c|c|}
\hline Variable & Sub variable & $\begin{array}{c}\text { Total } \\
\text { Average }\end{array}$ & $\%$ & Category \\
\hline \multirow{4}{*}{$\begin{array}{l}\text { Organizational } \\
\text { Culture }\end{array}$} & Cooperativeness & 89.6 & 80 & Strong \\
\hline & Innovativeness & 89.2 & 79.6 & Strong \\
\hline & Consistency & 89 & 79.46 & Strong \\
\hline & Effectiveness & 88.3 & 78.8 & Strong \\
\hline \multirow{3}{*}{$\begin{array}{c}\text { Information } \\
\text { Security } \\
\text { Management }\end{array}$} & Confidentiality & 91.8 & 82 & Very Strong \\
\hline & Integrity & 87.7 & 78.3 & Strong \\
\hline & Availability & 87.5 & 78.1 & Strong \\
\hline
\end{tabular}

Information security management analysis gave a different result. Confidentiality had the biggest value $(82 \%)$ and ñvery strongò category. It means that the implementation of information security management in the customer service office strongly emphasizes on the confidentiality aspect, including management of access right, secrecy, and safety of information. Integrity and availability aspect of information also are strongly implemented by the office, although it was not as strong as confidentiality. This can be accepted because in general the understanding of information security in most companies is more dominant to protect confidential information of their organization.

\section{B. Multiple Linear Regression Analysis}

Before doing the regression analysis, some statistical assumption testing or known as classical assumption test was needed. It consists of normality test, multicollinearity test, and heteroxidastity test. Normality test was performed using Kolmogorov-Smirnov test to observe whether residual data were normally distributed or not. The result of normality test for all dependent variable had value more than 0.05 as level of 
significance for passing the test. It means that, all data are normally distributed. To test the multicollinearity in this model, it was referred to the value of Variance Inflation Factor (VIF) and the value of tolerance for each independent variable. The result showed that the tolerance value was more than 0.1 and VIF value was less than 10. It means that there isnô any multicollinearity between the independent variables in the regression model. And the last, heteroxidastity test, rank Spearman test was used with a significance rate of 0.05 . The result of that test showed that all variables had a rank spearman value more than 0.05. It means there isnô any heteroxidastity for the model.

Based on the hypotheses, this paper had four multiple linear regression models to explore the relationship between organizational culture construct and information security management in the customer service office. The model was showed by a mathematical model number (2). H1 described the regression model of the organizational culture to information the security management and it can be seen in Table 4below.

TABLE IV. MULTIPLE LINEAR REGRESSION FOR H1

\begin{tabular}{|l|r|r|r|r|r|}
\hline \multirow{2}{*}{ Model } & \multicolumn{2}{|c|}{$\begin{array}{c}\text { Unstandardized } \\
\text { Coefficients }\end{array}$} & $\begin{array}{c}\text { Standardized } \\
\text { Coefficients }\end{array}$ & \multicolumn{1}{c|}{ S } & \\
\cline { 2 - 4 } & \multicolumn{1}{|c|}{ B } & Std. Error & \multicolumn{1}{c|}{ Beta } & & \\
\hline (Constant) & 5.649 & 2.597 & & 2.175 & .040 \\
Coop & 1.101 & .340 & .640 & 3.239 & .004 \\
1 Inno & .562 & .391 & .339 & 1.436 & .164 \\
Conc & .187 & .280 & .132 & .667 & .511 \\
Effect & -.700 & .489 & -.339 & -1.431 & .166 \\
\hline
\end{tabular}

It can be showed in a mathematical equation as follows::

$\mathrm{Y}=5.649+1.101 \mathrm{X} 1+0.562 \mathrm{X} 2+0.187 \mathrm{X} 3+(-0.700) \mathrm{X} 4+\mathrm{e}$

$\mathrm{H} 2$ described the regression model of the organizational culture to confidentiality aspect and it can be seen in Table 5 below.

TABLE V. MULTIPLE LINEAR REGRESSION FOR H2

\begin{tabular}{|c|c|c|c|c|c|}
\hline \multirow[t]{2}{*}{ Model } & \multicolumn{2}{|c|}{ Unstandardized Coefficients } & \multirow{2}{*}{$\begin{array}{c}\begin{array}{c}\text { Standardized } \\
\text { Coefficients }\end{array} \\
\text { Beta }\end{array}$} & \multirow[t]{2}{*}{$\mathrm{T}$} & \multirow[t]{2}{*}{ Sig. } \\
\hline & B & Std. Error & & & \\
\hline $\begin{array}{c}\text { (Consta } \\
\text { nt) }\end{array}$ & -.357 & 1.391 & & -.257 & .800 \\
\hline coop & .575 & .182 & .610 & 3.158 & .004 \\
\hline inno & .286 & .209 & .315 & 1.364 & .186 \\
\hline conc & .135 & .150 & .173 & .897 & .379 \\
\hline effect & -.322 & .262 & -.284 & -1.228 & .232 \\
\hline
\end{tabular}

It can be showed in mathematical equation as follows:

$\mathrm{Y} 1=-0.357+0.575 \mathrm{X} 1+0.286 \mathrm{X} 2+0.145 \mathrm{X} 3+(-0.322) \mathrm{X} 4+\mathrm{e}$

$\mathrm{H} 3$ described regression model of organizational culture to integrity aspect and it can be seen in Table 6 below.

TABLE VI. TABLE 6. MULTIPLE LINEAR REGRESSION FOR H3

\begin{tabular}{|c|c|c|c|c|c|c|}
\hline & \multirow[t]{2}{*}{ Model } & \multicolumn{2}{|c|}{$\begin{array}{c}\text { Unstandardized } \\
\text { Coefficients }\end{array}$} & $\begin{array}{c}\text { Standardized } \\
\text { Coefficients }\end{array}$ & \multirow[t]{2}{*}{$\mathrm{t}$} & \multirow[t]{2}{*}{ Sig. } \\
\hline & & B & Std. Error & Beta & & \\
\hline \multirow{5}{*}{1} & (Constant) & -.054 & .430 & & -.126 & .901 \\
\hline & Coope & .361 & .221 & .349 & 1.634 & .116 \\
\hline & Innov & .252 & .233 & .269 & 1.081 & .291 \\
\hline & consist & .309 & .202 & .314 & 1.529 & .140 \\
\hline & effect & -.191 & .222 & -.204 & -.861 & .398 \\
\hline
\end{tabular}

It can be showed in a mathematical equation as follows:

$\mathrm{Y} 2=-0.054+0.361 \mathrm{X} 1+0.252 \mathrm{X} 2+0.309 \mathrm{X} 3+(-0.191) \mathrm{X} 4+\mathrm{e}$

H4 described the regression model of the organizational culture to availability aspect and it can be seen in Table 7 below.

TABLE VII. TABLE 7. MULTIPLE LINEAR REGRESSION FOR H4

\begin{tabular}{|c|c|c|c|c|c|c|}
\hline & \multirow[t]{2}{*}{ Model } & \multicolumn{2}{|c|}{$\begin{array}{l}\text { Unstandardized } \\
\text { Coefficients }\end{array}$} & $\begin{array}{r}\text { Standardized } \\
\text { Coefficients }\end{array}$ & \multirow[t]{2}{*}{$\mathrm{t}$} & \multirow[t]{2}{*}{ Sig. } \\
\hline & & B & Std. Error & Beta & & \\
\hline \multirow{5}{*}{1} & (Constant) & 4.266 & 1.055 & & 4.045 & .001 \\
\hline & coop & .300 & .138 & .590 & 2.173 & .040 \\
\hline & inno & .139 & .159 & .284 & .874 & .391 \\
\hline & conc & -.101 & .114 & -.241 & -.889 & .383 \\
\hline & effect & -.175 & .199 & -.286 & -.879 & .388 \\
\hline
\end{tabular}

Source: calculation results of SPSS 21

It can be showed in mathematical equation as follows below.

$\mathrm{Y} 3=4.266+0.300 \mathrm{X} 1+0.139 \mathrm{X} 2+(-0.101) \mathrm{X} 3+(-0.175) \mathrm{X} 4+\mathrm{e}$

F-Test was conducted to explain whether sub variables of organizational culture (i.e. cooperativeness, innovativeness, consistency, and effectiveness) as independent variables simultaneously affect each sub variable of the dependent variable. Results of F-Test using SPSS 21 is showed in Table 8 below.

TABLE VIII. TABLE 8. RESULT OF F-TEST

\begin{tabular}{|c|c|c|c|c|}
\hline $\begin{array}{c}\text { Regression } \\
\text { Model }\end{array}$ & $\begin{array}{c}\mathrm{F}_{\text {counting }} \text { for } \\
\text { each model }\end{array}$ & $\mathrm{F}_{\text {Table }}$ & P-value & Sig \\
\hline $\mathrm{Y}$ & 8.742 & 2.80 & 0.000 & 0.05 \\
\hline Confidentiality & 9.434 & 2.80 & 0.000 & 0.05 \\
\hline Integrity & 4.571 & 2.80 & 0.007 & 0.05 \\
\hline Availability & 1.931 & 2.80 & 0.139 & 0.05 \\
\hline
\end{tabular}

Hypothesis is accepted if $\mathrm{F}_{\text {counting }}>\mathrm{F}_{\text {table }}$ and p-value < Significance rate (5\%). Therefore, for each model, we will get the result of hypothesis testing as below. 
a) Multiple linear regression model for Information security management variable $(\mathrm{Y})$ resulted $\mathrm{F}_{\text {counting }}=8.742$ (more than 2.80) and p-value $=0.000$ (less than 0.05). It can be concluded that $\mathrm{H} 1$ is accepted which means organizational culture significantly affected the information security management implementation in that office.

b) Multiple linear regression model for Confidentiality (Y1) resulted $\mathrm{F}_{\text {counting }}=9.434$ (more than 2.80 ) and $\mathrm{p}$-value $=$ 0.008 (less than 0.05). It can be concluded that $\mathrm{H} 2$ is accepted, which means organizational culture significantly affected the confidentiality aspect of the information security in that office.

c) Multiple linear regression model for Integrity (Y2) resulted $\mathrm{F}_{\text {counting }}=4.509$ (more than 2.80) and $\mathrm{p}$-value $=$ 0.008 (less than 0.05). It can be concluded that $\mathrm{H} 3$ is accepted, which means organizational culture significantly affected the integrity aspect of the information security in that office.

d) Multiple linear regression model for Availability (Y3) resulted $\mathrm{F}_{\text {counting }}=1.931$ (less than 2.80 ) and $\mathrm{p}$-value $=$ 0.139 (more than 0.05 ). It can be concluded that $\mathrm{H} 4$ is rejected, which means organizational culture did not significantly affect the availability aspect of the information security in that office.

Determinant Coefficient $\left(R^{2}\right)$ measures how good all independent variable can explain varians of its dependent variables. Value of $R 2$ from all regression models in this research can be showed in Tabel 9 below.

TABLE IX. DETERMINANT CORELLATION COEFFICIENT ANALYSIS (R2)

\begin{tabular}{|c|c|c|c|c|}
\hline & $\begin{array}{c}\text { Information Security } \\
\text { Management }\end{array}$ & Confidentiality & Integrity & Availability \\
\hline $\mathrm{R}^{2}$ & 0.603 & 0.621 & 0.443 & 0.251 \\
\hline
\end{tabular}

Source: calculation results of SPSS 21

From Table 9, it can be explained that the information security management in the customer service office can be affected by $60 \%$ by its organizational culture. The rest $40 \%$ are other variables that is not included in this research. Partially, the culture also has a contribution of $62 \%$, which affected the confidentiality, $44 \%$ integrity, and $25 \%$ availability of information security in that office. However, based on F-Test result, the contribution of $25 \%$ does not significantly affect the availability aspect. The multiple regression models from this research can also be described in Figure 2 below.

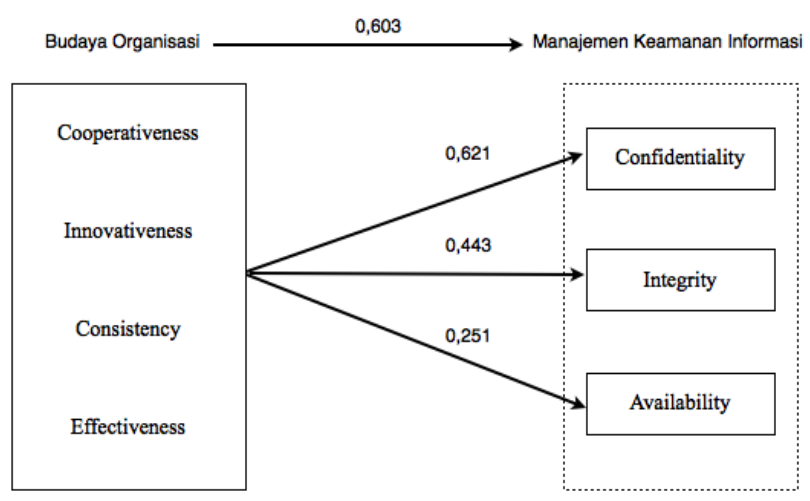

Fig. 2. Multiple Linear Regression Model

\section{CONCLUSION}

From the descriptive analysis, we can conclude that the telecommunication provider customer service office, as a case study in this research, is not dominated by any one of four types of that organizational culture. Nevertheless, cooperativeness has the highest score among the other types, which means it is the strongest culture adapted in that office. Meanwhile, for the information security triad, confidentiality is the most dominating aspect in the implementation of information security management in the office. From the statistical analysis, all hypotheses in this research are accepted, except $\mathrm{H} 4$ that defines the relationship between organizational culture and availability as a part of information security management. It shows that only availability aspect that is not significantly affected by organizational culture, although simultaneously the culture is significantly affected the information security management.

For the further research, more customer service offices from the same telecommunication provider can be used in order to compare the result, whether it will give the same relationship or not. Furthermore, customer service office from different providers can also be used to observe the organizational culture and its impact to information security triad.

\section{References}

[1] T.R. Peltier, Information Security Fundamentals, Second Edition, Boca Raton: Taylor \& Francis Group, LLC, 2014.

[2] L.S. Fan, and N.H.N. Alwi, ñE-Learning and Information Security Management,ò International Journal of Digital Society (IJDS), vol. 1, no. 2, June 2010, pp.148-156.

[3] S.E. Chang, and C.S. Lin, ñExploring Organizational Culture for Information Security Management,ò Industrial Management \& Data System, vol. 107, no. 3, 2007, pp. 438-458.

[4] S.E. Chang, and C.B. Ho, ñOrganizational Factors to The Effectiveness of Implementing Information Security Management,ò Industrial Management \& Data System, vol. 106, no. 3, 2006, pp. 345-361.

[5] P. Ifinedo, ñInformation Technology Security Management Concerns in Global Financial Services Institutions; Is National Culture a Differentiator?,ò Information Management \& Computer Security, vol. 17 , no. 5, 2009, pp. 372-387. 
[6] E. H. Schein, Organizational Culture and Leadership, San Francisco: Jossey Bass, 1992.

[7] B. Cushway, et.al, Perilaku dan Desain Organisasi (terjemahan), Jakarta: Elex Media Komputindo, 2000.

[8] A.S. Munandar, Buku Psikologi Industri dan Organisasi. Penerbit universitas indonesia (UI. Press), Jakarta, Jakarta: UI Press, 2008.

[9] S.K.J. Lee, and K. Yu, ñCorporate Culture and Organizational Performance, ò Journal of Managerial Psychology, vol. 19, no. 4, 2004, pp. $340-359$.

[10] E. Claver, et.al, ñThe Performance of Information Systems Through Organizational Culture, ò Information Technology \& People, vol. 14, no. 3, 2001, pp. 247-260,

[11] L.A. Gordon, and M.P. Loeb, ñThe Economics of Information Security Investment,ò ACM Transactions on Information \& System Security, vol. 5, no. 4, November 2002, pp. 438-457.
[12] P.K. Sari, and Candiwan, ñMeasuring Information Security Awareness of Indonesian Smartphone Users,ò TELKOMNIKA, vol. 12, no. 2, June 2014, pp. 493-500.

[13] A.T. Ferdinand, Metode Penelitian Manajemen: Pedoman Penelitian untuk Penulisan Skripsi, Tesis dan Disertasi, Semarang: BP Undip, 2006.

[14] Sugiyono, Metode Penelitian Kuantitatif Kualitatif dan R\&D, Bandung: Alfabeta, 2012.

[15] U. Sekaran, and R. Bougie, Research Methods for Business: A Skill Buildin Approach, John Wiley \& Sons, 2010.

[16] D. Mani, K.K.R. Choo, and S. Mubarak, ñInformation Security in the South Australian Real Estate Industry,ò Information Management \& Computer Security, vol. 22, no. 1, 2014, pp. 24-41. 